\title{
Formulation of Decaffeinated Instant Coffee Effervescent Tablet
}

\author{
Andi Dharmawan ${ }^{(*)}$, Sukrisno Widyotomo ${ }^{1)}$, Hendy Firmanto ${ }^{1)}$, and Bayu Setyo Abdurizal ${ }^{1)}$ \\ ${ }^{1}$ Indonesian Coffee and Cocoa Research Institute, Jln. PB Sudirman No. 90, Jember, Indonesia. \\ ${ }^{*}$ Corresponding author: dharmawan_andi@ymail.com \\ Received: 31 October 2016 / Accepted: 26 November 2016
}

\begin{abstract}
Decaffeinated coffee is an alternative for caffeine intollerant consumer as a safe and practical choice. However, since decaffeination process employ high temperature extraction, the coffee produced usually possesses inferior sensory qualities. This research was aimed to get an optimum formulation of effervescent coffee tablet that has good physical and sensory quality. In this research, effervescent coffee tablet was formulated with three different ratios of the decaffeinated instant coffee and effervescent reagent (citric acid and sodium bicarbonate), namely $1.5: 1 ; 1: 1$; and $1: 1.5(\mathrm{w} / \mathrm{w})$ weighed in $3 \mathrm{~g}$ per tablet serving. Sensory evaluation was carried out organoleptically in several criteria such as flavors, aromas, and colors on $40 \mathrm{~mL}, 80 \mathrm{~mL}$, and $120 \mathrm{~mL}$ of the solution. Futher, physical quality evaluation was done by measuring its weight uniformity, hardness, friability, and run time which then calculated by statistic analytical method to decide the best formulation. Based on the result, the best formulation of effervescent coffee tablet was $1: 1.5(\mathrm{w} / \mathrm{w})$ due to its shortest run time (4.2 minutes), good weight uniformity and hardness value, $1.16 \pm 0.03 \mathrm{~g} / \mathrm{cm}^{3}$ dan $6.7 \pm 0.5 \mathrm{~kg}$, respectively, while friability value was the smallest (2\%) compared to other formulations. The brewing of this formulation in $40 \mathrm{~mL}$ water also had best sensory profiles in term of aroma, color and flavor.
\end{abstract}

Keywords: decaffeinated instant coffee, tablets, effervescent, flavours

\section{INTRODUCTION}

Coffee is one of agriculture commodities serving as beverage and contains caffeine which acts as stimulant. Instant coffee contains 66-100 mg of caffeine per serving (Sadock \& Sadock, 2007). It is useful to help coping with asthma and kidney stones. Caffeine is routinely treated to prematurely born babies to suppress respiratory disorders. Caffeine can also increase working capacity of aspirin and other pain reliever medicines. This is the reason why fever and headache reliever contain caffeine (Norton et al., 2011).

Caffeine intolerant people are affected by insomnia, palpitations, headache, tremor, anxiety, nausea, vomiting, restlessness, trembling, increased blood pressure and respiration (Bawazeer \& Alsobahi, 2013). Pregnant women consuming one to three cups of coffee per day might increase miscarriage risk by $30 \%$ (Estien, 2015). To ensure coffee could be consumed by consumers who are less tolerant to caffeine, it is necessary to lower caffeine level by using decaffeination process. Low caffeine coffee processed through decaffeination utilizing organic solvent ethyl acetate and robusta coffee bean could decrease the coffee taste (Widyotomo et al., 2009). Coffee beans size directly affects the flavor contained in the post-processed coffee. Smaller sized coffee 
beans will decrease flavor due to faster extraction process (Primadia, 2009). The longer the decaffeination process takes place, the resulting flavors will be inferior compared to pre-processing. Decrease in caffeine ranges from $83 \%$ to $90 \%$ (Widodo et al., 2010).

Citric acid is commonly used as a food acid and relatively cheap. This type of acid has high solubility, high acidity and is available in granular, anhydrous and monohydrate forms. In addition, it is also available in powder form and has hygroscopic attribute. Therefore, handling and storage need special attention (Rowe et al., 2009). Sodium bicarbonate is white crystalline powder possessing salty taste, dissolveable in water, and not hygroscopic. Sodium bicarbonate at relative humidity above $85 \%$ will quickly absorb water in the environment and will lead to decomposition and loss of carbon dioxide so it is required to be stored in sealed storage. Sodium bicarbonate is main source of forming material in producing carbon dioxide. This compound is completely dissolveable in water, not hygroscopic, cheap, and widely available in the market in five levels of particle size ranging from fine powder to free flowing uniform granules, edible and is widely used in food products such as baking soda. Sodium bicarbonate is the weakest alkali sodium, possessing pH 8.3 in aqueous solution and $0.85 \%$ concentration. This substance produces approximately $52 \%$ of carbon dioxide as dissolving agent and $\mathrm{CO}_{2}$ source in effervescent tablets (Rohman, 2015).

Maltodextrin is carbohydrate type possessing high molecular weight which is a modified starch and acid. Maltodextrin easily dissolves in water, quickly dispersed, not lumpy and stabler compared to starch. Maltodextrin functions as a carrier of active food ingredients such as flavor and coloring materials also dissolve in water and filler material because it can increase weight of product in powder form. Maltodextrin consists of glucose which able to bind water which in turn reduce dissolved oxygen, as a result of this process, oxidation process can be prevented. Maltodextrin is dissolveable in water, stabler in heat, so it can protect volatile compounds and compounds sensitive to heat or oxidation (Anwar, 2002). Additional calcium is used as a fortification to enrich the nutritional value. In turn, it would be beneficial to health, while the coffee natural essence is used as an additive amplifier for coffee aroma and taste. These materials easily dissolve in water, thus simplifying reaction in the dissolving process.

Therefore improving low-caffeine coffee flavor can be done by processing effervescent coffee tablet for its distinctive flavor. It will possess distinct color, smell, taste and the ability to produce carbon dioxide, providing fresh taste akin to soda water. The gas will cover the bitter taste and also to simplify dissolving process without involving manual stirring (Permana et al., 2012). This research was aimed to get an optimum formulation of effervescent coffee tablet that has good physical and sensory quality.

\section{MATERIALS AND METHODS}

In this study, low caffeine effervescent coffee tablets were processed in three treatments and repeated formulation as follows: 1:1.5 (w/w), 1:1 (w/w) and 1.5:1 (w/w). The formulas were prepared from a mixture of low caffeine instant coffee containing citric acid, sodium bicarbonate, food additives such as maltodextrin, coffee natural essences, and fortified calcium. Dosage used was $3 \mathrm{~g}$ per tablet passed through mesh sieve 16 (Table 1). Tablet weight was adjusted to molding machine using TDP 5. Pressure was applied manually to compress material inside molding machine therefore constant pressure magnitude could not be determined. Standard tablet shape was 
round-shaped with $2.00 \mathrm{~cm}$ diameter and $0.85 \mathrm{~cm}$ thickness. Quality testing was done physically to measure weight uniformity, hardness, friability, and run time. Organoleptic test was conducted to determine taste, color and aroma in solubility level of $40 \mathrm{~mL}, 80 \mathrm{~mL}$ and 120 $\mathrm{mL}$. Assessment conducted by 20 panelists on organoleptic test and the recorded data were analyzed of the variance and mean differentiated by Duncan multiple range cordance to physical product quality review.

Effervescent tablets would react with acid and alkaline bicarbonate when mixed with water. To avoid early reactions and maintain product stability, acid and alkaline bicarbonate were mixed shortly before molding process (Solomon, 2007). In addition, drying process was conducted at $50^{\circ} \mathrm{C}$ to minimize water content in the material and was conducted before mixing process. Citric acid was mixed homogeneously with low caffeine instant coffee and calcium, while sodium bicarbonate was mixed until it homogeneous with maltodextrin and natural coffee essences. Before molding process, materials were mixed in room temperature of $20^{\circ} \mathrm{C}$ and $20 \%$ of relative humidity ( $\mathrm{RH})$ in order to ensure the environment did not affect water content in the materials.

Table 1. Formulations of effervescent coffee tablet

\begin{tabular}{lccc}
\hline \multirow{2}{*}{ M aterials } & \multicolumn{3}{c}{ Formulations (w/w) } \\
\cline { 2 - 4 } & $1.5: 1$ & $1: 1$ & $1: 1.5$ \\
\hline Decafeinated instant coffee & $1.50 \mathrm{~g}$ & $1.20 \mathrm{~g}$ & $0.90 \mathrm{~g}$ \\
Maltodextrin & $0.30 \mathrm{~g}$ & $0.30 \mathrm{~g}$ & $0.30 \mathrm{~g}$ \\
Citric acid & $0.45 \mathrm{~g}$ & $0.60 \mathrm{~g}$ & $0.73 \mathrm{~g}$ \\
Sodium bicarbonate & $0.55 \mathrm{~g}$ & $0.70 \mathrm{~g}$ & $0.87 \mathrm{~g}$ \\
Natural coffee essence & $0.15 \mathrm{~g}$ & $0.15 \mathrm{~g}$ & $0.15 \mathrm{~g}$ \\
Calcium & $0.05 \mathrm{~g}$ & $0.05 \mathrm{~g}$ & $0.05 \mathrm{~g}$ \\
\hline Weight & & $3 \mathrm{~g}$ & \\
\hline
\end{tabular}
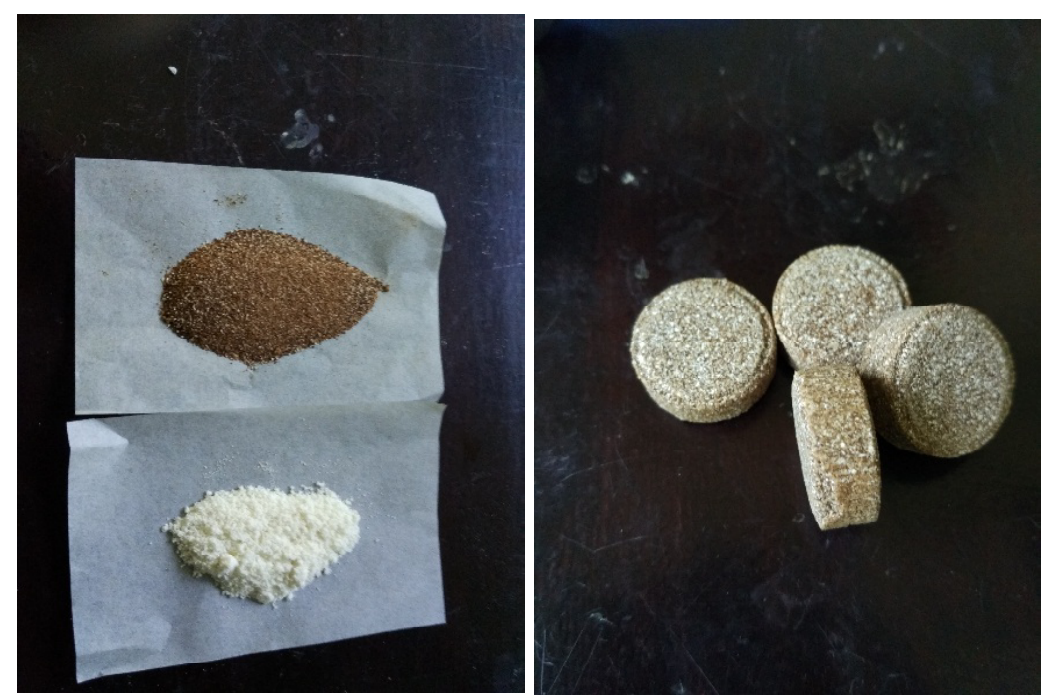

Figure 1. Formulation of the effervescent decaffaeinated coffee tablet 


\section{RESULTS AND DISCUSSION}

Three formulas were prepared and repeated in testing, then analyzed for product physical quality such as density, hardness, and friability tests as presented in Table 2 . This formulation was based on work of Limyati (2009) that by adding effervescent mix $50 \%$ (1:1) compound to produce the best carrot effervescent powder. Thus, formula concentration or composition in this study was prepared to determine the effect of different compounds. The compounds would produce effervescence in low caffeine instant coffee which acted as an active ingredient. Comparison between citric acid and sodium bicarbonate was based on stoichiometry rules, i.e one molecule of citric acid will react to one molecule of sodium bicarbonate. It was done in order to determine sodium bicarbonate and citric acid comparison, which resulted in 10:7 (Siregar, 2010).

Data analysis in Table 2 exhibits three formulas density value as follows: $1.10 \pm$ $0.05 \mathrm{~g} / \mathrm{cm}^{3}$ for $1.5: 1(\mathrm{w} / \mathrm{w}), 1.15 \pm 0.03 \mathrm{~g} / \mathrm{cm}^{3}$ for $1: 1(\mathrm{w} / \mathrm{w})$, and $1.16 \pm 0.03 \mathrm{~g} / \mathrm{cm}^{3}$ for 1:1.5 (w/w) formula, which were greater than water density $\left(1 \mathrm{~g} / \mathrm{cm}^{3}\right)$, the product will sink when poured into water to ensure better dissolve process. A reaction would occur when the product is mixed with liquid material. Density is affected by material mass and volume. The larger the volume, the smaller density values would be. Formula 1:1.5 (w/w) possessed more reactant material composition than active substance. Product volume became smaller during molding process; therefore it had greater density value compared to other formulas. This was caused by vibration or pressure as well as particle size that affected density. Ditjen BKAK (2014) stated that active substance (low caffeine instant coffee) should be the larger part of the tablet, density test would be sufficient in representing compound uniformity and vice versa. Pharmacopoeia generally require for coated tablets or tablets containing $50 \mathrm{mg}$ or less active substance. Active substance weight should be less than $50 \%$ compared to its initial weight in preparation phase. It is required to conduct content uniformity test (formulations) in each tablet. Thus, 1:1.5 (w/w) formula had the best density value.

Based on Indonesian Pharmacopoeia (2014), effervescent tablet is required to be tested in the range of 4-10 kg. Hardness testing is conducted to determine product durability against physical threat such as internal and external shocks, falls, or crushing damage. Based on the test results shown in Table 2, it indicated that low caffeine coffee effervescent produced in each formula was still in the range of requirements, which exhibited as follows: $5.67 \pm 0.50 \mathrm{~kg}$ in formula 1.5:1 $(\mathrm{w} / \mathrm{w}), 6.67 \pm 0.50 \mathrm{~kg}$ formula $1: 1(\mathrm{w} / \mathrm{w})$ and $6.00 \pm 0: 50 \mathrm{~kg}$ in formula $1: 1.5(\mathrm{w} / \mathrm{w})$. Hardness testing indicates the product physical quality capable of withstanding against shocks, falls, or crushing damage. It guarantees intact product physical appearance. If the

Table 2. Physical qualities of effervescent coffee tablet used

\begin{tabular}{lccc}
\hline \multirow{2}{*}{ Characteristic } & \multicolumn{3}{c}{ Formulation (w/w) } \\
\cline { 2 - 4 } & $1.5: 1$ & $1: 1$ & $1: 1.5$ \\
\hline Thickness $(\mathrm{cm})$ & $0.85 \pm 0.02$ & $0.80 \pm 0.02$ & $0.78 \pm 0.02$ \\
Volume $\left(\mathrm{cm}^{3}\right)$ & $2.7 \pm 0.1$ & $2.57 \pm 0.06$ & $2.49 \pm 0.08$ \\
Weight uniformity $\left(\mathrm{g} / \mathrm{cm}^{3}\right)$ & $1.10 \pm 0.05$ & $1.15 \pm 0.03$ & $1.16 \pm 0.03$ \\
Friablity $(\%)$ & 14 & $6.67 \pm 0.50$ & 2 \\
Hardness $(\mathrm{kg})$ & $5.67 \pm 0.50$ & 7.8 & $6.00 \pm 0.50$ \\
Run time (minute) & 11.3 & & 4.2 \\
\hline Notes: Figures are means \pm standard errors & &
\end{tabular}

Notes: Figures are means \pm standard errors 
tablet possess less than $4 \mathrm{~kg}$ hardness, that product could easily be damaged or crumbled. If more than $10 \mathrm{~kg}$, the product hardens which makes it more difficult to dissolve in water (Solomon, 2007). This hardness value is affected by the material compound binding such as sugars contained in instant coffee and maltodextrin. Thus, more content in instant coffee and maltodextrin produce higher hardness values (Anief, 2015). In this study, formula 1:1 (w/w) had the highest hardness value. It is caused by balanced composition between the active ingredient and alkaline bicarbonate which serves as adhesive to produce a strong bond. Other formula composition did not had balance between active compound and alkaline bicarbonate even when using similar amount of content. However, fragility test percentage did not exhibit adequate results. Required fragility percentage limits suggested by Indonesian Pharmacopoeia regarding effervescent preparation is at maximum of $1 \%$. Fragility test percentage exhibited in Table 2 is as follows: $1.5: 1(\mathrm{w} / \mathrm{w})$ is $14 \%, 1: 1(\mathrm{~b} / \mathrm{b})$ is $5 \%$, and $1: 1.5(\mathrm{w} / \mathrm{w})$ is $2 \%$. Formula $1.5: 1$ $(\mathrm{w} / \mathrm{w})$ has the highest percentage of fragility compared to other formulas. Fragility test indicates product quality to withstand against impact or other physical threat to ensure product integrity (Winarno, 2002). Thus, the fewer the composition of active ingredient compound for low caffeine instant coffee the smaller fragility value would be, and vice versa.

Solubility testing involves examining required time for tablet to disintegrate into granules or dissolved in solution. Appropriate time lenght is at maximum of 2 minutes depending on active substance or material used in accordance to its monograph (Jaysukh, 2009). Tablets do not dissolve well should the time required is longer, which opposed main manufacturing objective which requires practicality and quickness. This test is useful as preliminary testing tool to examine early formulation process and routine quality control procedures. Based on test results, fastest time required for tablets to dissolve is as follows: $1: 1.5(\mathrm{w} / \mathrm{w})$ for 4.2 minutes. Compared to other formulas, those resulted in 1.5:1 (w/w) for 11.3 minutes and 1:1 $(\mathrm{w} / \mathrm{w})$ for 7.8 minutes. Time required for material to dissolve is affected by reactants availability in the product. The more reactants in the compound will result in chemical reaction that enables faster dissolving process. Each formula does not meet the requirement, as they surpassed required 2 minutes.

In addition, hedonic organoleptic test conducted for taste, color and aroma parameter to examine preferred formula. The compound was dissolved in $40 \mathrm{~mL} ; 80 \mathrm{~mL}$; and $120 \mathrm{~mL}$ water with $23^{\circ} \mathrm{C}$ temperature. Based on

Table 3. Organoleptic test results of the effervescent coffee tablets

\begin{tabular}{lcccc}
\hline Formulation & Brewing volume & Color & Aroma & Flavour \\
\hline $1: 1(w / w)$ & $40 \mathrm{~mL}$ & $4.00 \pm 0.82 \mathrm{e}$ & $2.46 \pm 0.88 \mathrm{a}$ & $3.23 \pm 1.01 \mathrm{a}$ \\
& $80 \mathrm{~mL}$ & $3.15 \pm 1.14 \mathrm{abc}$ & $2.54 \pm 0.97 \mathrm{a}$ & $2.85 \pm 0.89 \mathrm{a}$ \\
& $120 \mathrm{~mL}$ & $2.85 \pm 1.14 \mathrm{ab}$ & $2.31 \pm 0.85 \mathrm{a}$ & $2.54 \pm 0.87 \mathrm{a}$ \\
$1: 1.15(\mathrm{w} / \mathrm{w})$ & $40 \mathrm{~mL}$ & $3.92 \pm 0.64 \mathrm{de}$ & $1.92 \pm 1.12 \mathrm{a}$ & $2.77 \pm 1.30 \mathrm{a}$ \\
& $80 \mathrm{~mL}$ & $3.38 \pm 0.65 \mathrm{abcde}$ & $2.54 \pm 1.05 \mathrm{a}$ & $3.08 \pm 0.95 \mathrm{a}$ \\
$1: 2(\mathrm{w} / \mathrm{w})$ & $120 \mathrm{~mL}$ & $3.23 \pm 0.73 \mathrm{abcd}$ & $2.69 \pm 1.03 \mathrm{a}$ & $2.69 \pm 0.85 \mathrm{a}$ \\
& $40 \mathrm{~mL}$ & $3.85 \pm 0.90 \mathrm{cde}$ & $2.54 \pm 1.27 \mathrm{a}$ & $3.15 \pm 0.90 \mathrm{a}$ \\
& $80 \mathrm{~mL}$ & $3.54 \pm 0.78 \mathrm{bcde}$ & $2.69 \pm 1.11 \mathrm{a}$ & $3.23 \pm 1.01 \mathrm{a}$ \\
\hline
\end{tabular}

Note : ${ }^{1)}$ mean \pm standard deviation in the same column followed with same letter are not significantly different according to Duncan multiple range test (DMRT) at $\alpha=5 \%$. 
the result, there was significant difference for color, while taste and aroma were not significantly different. Tests provided preference value of 1-5 which respectively indicated: strongly disagree, disagree, neutral, agree, and strongly agree. The test involved 20 pane-lists.

Based on variance analysis using Anova and Duncan tests, it showed that preferred color was present in formula 1:1.5 (w/w) dissolved in $40 \mathrm{~mL}$ water. Panelists may flavor color parameter available in formula 1.5:1 (w/w) on average out of 20 panelists. Nevertheless they drew conclusion based on significant preference level, considering tested tablet physical quality, and compared time required for the compound to dissolve in the formulas $1.5: 1(\mathrm{w} / \mathrm{w})$ to $1: 1.5(\mathrm{w} / \mathrm{w})$. Formula 1:1.5 (w/w) had faster dissolving time compared to formula 1.5:1 (w/w). Initially brewed low caffeine coffee preferred parameter value are exhibited aroma 2.1 (disagree), taste 2.4 (disagree), and color 2.7 (neutral) in $40 \mathrm{~mL}$ serving. Preference value for effervescent low caffeine coffee increased to 2.54 (neutral), 3.15 for flavors (neutral), and 3.85 for color (agree) as shown in Figure 2. Thus, low caffeine effervescent coffee tablet is one method to improve the low-caffeine coffee taste.

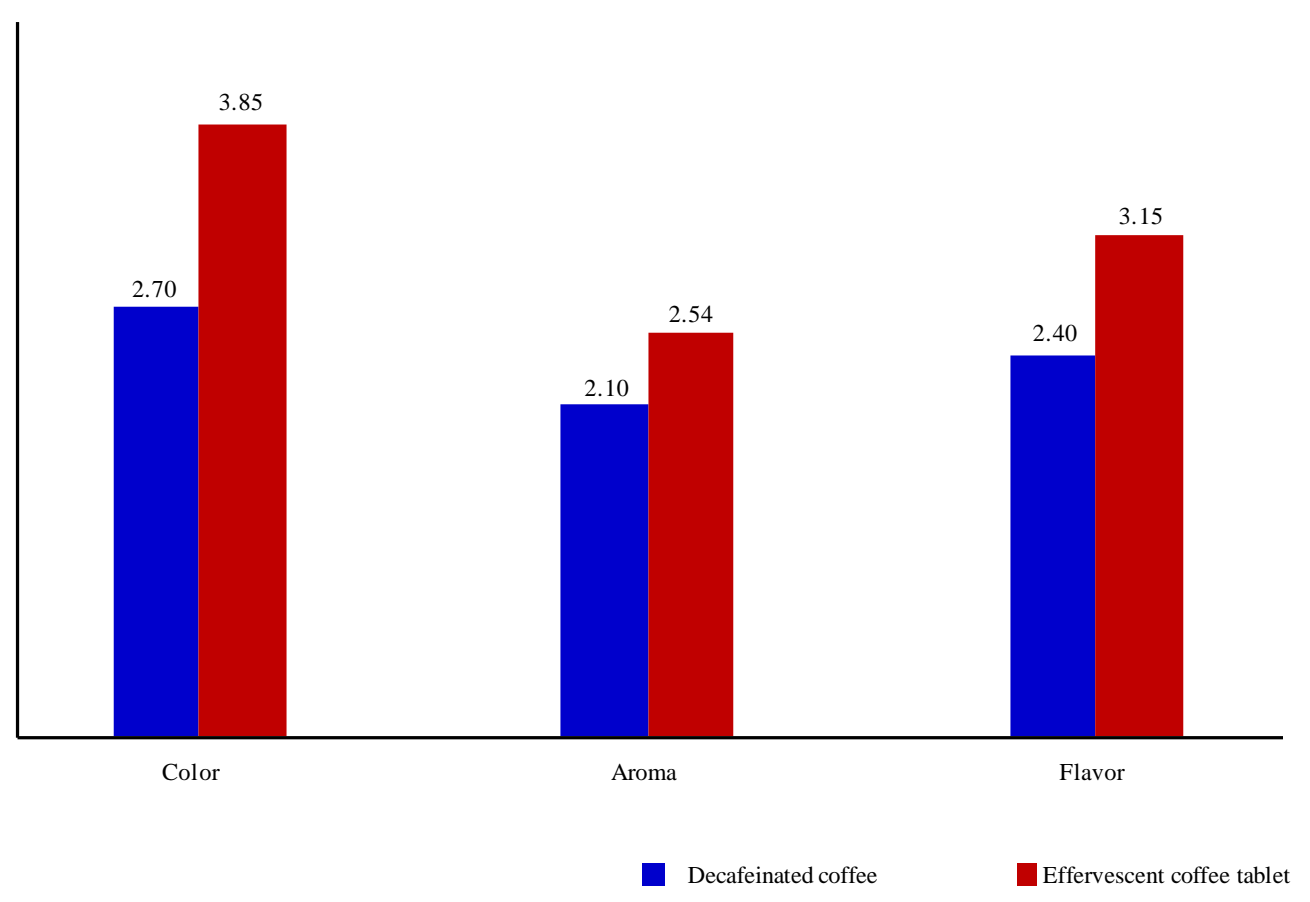

Figure 2. Comparison of hedonic result between effervescent coffees with low caffeine instant coffee 


\section{CONCLUSION}

Best formula ratio for low caffeine instant coffee and reactant compound obtained in this research was $1: 1.5(\mathrm{w} / \mathrm{w})$. The formula was created using composition low caffeine instant coffee $0.9 \mathrm{~g}$, maltodextrin $0.3 \mathrm{~g}$, citric acid $0.73 \mathrm{~g}$, sodium bicarbonate $0.87 \mathrm{~g}$, natural essence $0.15 \mathrm{~g}$, and calcium $0.05 \mathrm{~g}$ for $3.0 \mathrm{~g}$ tablet for $40 \mathrm{~mL}$ serving. The physical characteristic was 4.2 minutes dissolve time which was shorter than the other formulas. In addition, the formula has fragility percentage of $2 \%$ which was lower compared to other formulas. The product was against physical threats such as shocks, cracks, fracture, friction, or crumbled. In addition, based on organoleptic test for prefered characteristics, this formula possessed preference level color for 3.85 (agree), aroma 2.54 (neutral), and taste 3.15 (neutral). The values were larger than the other formulas for $40 \mathrm{~mL}$ servings. However, this study could be developed further by researching method to improve friability level and run time process in accordance to Indonesian Pharmacopeia regulations.

\section{ACKNOWLEDGEMENT}

The authors would like to extend their gratitude to Director of Indonesian Coffee and Cacao Research Institute (ICCRI) for allowing this research to be published, as well as technicians in Mechanization Laboratorium of ICCRI, for their help in conducting this research. Thanks to Mrs. Solihatus Sallama, A.Md and Mrs. Titin Nur Farida, S.Farm who helping and preparing for this research.

\section{REFERENCES}

Anwar, E. (2002). Pemanfaatan maltodekstrin dari pati singkong sebagai bahan penyalut tipis tablet. Makara Sains, 6, 50- 54.
Bawazeer N.A. \& N.A. Al Sobahi (2013). Prevalence and side effects of energy drink consumption among medical students at Umm Al-Qura University, Saudi Arabia. International Journal of Medical Students, 1, 104- 8.

Ditjen BKAK (2014). Farmakope Indonesia. Jilid V. Direktorat Jenderal Bina Kefarmasian dan Alat Kesehatan, Kementerian Kesehatan RI, Jakarta.

Estien M.S \& Yazid (2015). Fakta Tentang Kopi. AAK Husada. Gresik.

Jaysukh, J.; A. Dhaval \& R. Kantilal (2009). Orally disintegrating tablets: A review. Tropical Journal of Pharmaceutical Research, 8, 161- 172.

Limyati, V.Y. (2009). Formulasi Serbuk effervescent dari Ekstrak Wortel (Daucus carota $L$ ). Tesis, Fakultas Teknologi Pertanian, Universitas Andalas, Padang.

Norton, T.R.; A.B. Lazev \& M.J. Sulivan (2011). The "Buzz" on caffeine: patterns of caffeine use in a convenience sample of college students. Journal of Caffeine Research, 1, 35-40.

Permana, W.; S. Prabawati \& D.A. Setiabudi (2012). Sifat antioksidan bubuk kulit buah manggis instan dan aplikasinya untuk makanan fungsional berkarbonasi. Jurnal Pascapanen, 9, 88-95.

Primadia, A.D. (2009). Pengaruh Peubah Proses Dekafinasi Kopi dalam Reaktor Kolom Tunggal terhadap Mutu Kopi. IPB Press. Bogor.

Rohman, A. (2015). Analisis Obat. UGM Press, Yogyakarta.

Rowe, R.C.; P.J. Sheskey \& M.E. Quinn (2009). Handbook of Pharmaceutical Excipients. Lexi-Comp: American Pharmaceutical Association, Inc.

Sadock B.J. \& V.A. Sadock (2007). Kaplan \& Sadock's Synopsis of Psychiatry: Behavioral Sciences Clinical Psychiatry. 10th Edition. Lippincott Williams \& Wilkins, New York. 
Siregar, C.J.P. \& S. Wikarsa (2010). Teknologi Farmasi Sediaan Tablet: Dasar-Dasar Praktis. EGC. Jakarta.

Sulaiman, T.N.S. (2007). Teknologi dan Formulasi Sediaan Tablet, Mitra Communications Indonesia. Yogyakarta.

Widodo, R.A. \& F. Afrilliano (2010). Rancang Bangun Prototipe Alat Dekafeinasi Kopi Biji dengan Sistem Pemanasan. Program Studi Teknik Pertanian UNSRI. Indralaya.
Widyotomo, S. (2009). Karakteristik proses dekafeinasi kopi Robusta dalam reaktor kolom tunggal dengan pelarut etil asetat. Pelita Perkebunan, 25, 101- 105.

Winarno, F.G. (2002). Kimia Pangan dan Gizi, Jakarta.

$* * 0 * *$ 